\title{
THE EFFECT OF TRANSFORMATIONAL LEADERSHIP ON EMPLOYEE PERFORMANCE WITH EMPLOYEE ENGAGEMENT AS A MEDIATION VARIABLE
}

\author{
Muhammad Donal Mon ${ }^{1)}$, Robin ${ }^{2)}$, Oparton J. Tarihoran ${ }^{3)}$ \\ ${ }^{1)}$ Doctoral of Strategic Management, Faculty of Economics, Universitas Internasional Batam, Indonesia. \\ ${ }^{2)}$ Doctoral of of Finance, Faculty of Economics, Universitas Internasional Batam, Indonesia \\ ${ }^{3)}$ Student Magister Management, Faculty of Economics, Universitas Internasional Batam, Indonesia \\ Corresponding author: Muhammad.Donal@uib.ac.id
}

\begin{abstract}
This research aims to determine the significant influence between transformational leadership on employee performance and employee engagement as a mediating variable for employees of Certain Functional Officers Immigration Analyst under the Provincial Office of the Ministry of Law and Human Rights Kepulauan Riau. This research is a quantitative study using primary data. The population in the study amounted to 216 employees, with a total sample of 163 employees who filled out a questionnaire measured by using a Likert scale. To answer the research hypothesis formulation, the data collection results were analyzed using the Partial Least Square (PLS) method and assisted by SmartPLS 3.0 software. Based on the results of the analysis using the Partial Least Square (PLS) method, it was found that two components of transformational leadership, namely idealized influence and inspirational motivation, have a positive but insignificant effect on employee performance, while the other two components, intellectual stimulation, and individualized consideration have no effect. Moreover, when the four components of transformational leadership (idealized influence, inspirational motivation, intellectual stimulation, and individualized consideration) are mediated by the employee engagement variable, there is a strengthening of the influence of transformational leadership on employee performance.
\end{abstract}

Keywords: Transformational Leadership, Employee Performance, And Employee Engagement.

\section{Introduction}

Concerning the times, every organization must provide excellent and satisfactory service to every constituent associated with the organization, including government organizations. Every government organization will strive to provide good services, especially to the community as users of government services. Government organizations have duties and functions in carrying out the development process in various sectors ranging from the most basic level, such as village government, to the central government's highest level. The achievement of the performance goals of government organizations is marked by the adequate performance of employees in completing tasks. All government agencies so that all employees have the ability to carry out their duties and functions effectively, efficiently, productively, and professionally in providing services to the community. Good service aims to government agencies produce employees who have high quality and competitiveness, whose benefits will be enjoyed by the public as users of government organization services.

Based on Law no. 5 of 2014, Civil Servants or State Civil Apparatus, which is usually abbreviated as ASN, are government employees based on a work agreement or who are appointed through a staffing officer and then assigned tasks and responsibilities into a government position and are given a salary based on the prevailing laws and regulations. Set. An ASN has a role in government as a planner, implementer, and supervisor in implementing government duties in the form of services to the community. Besides that, an ASN also acts as an agent of national development by carrying out professional public policy tasks, not being involved in practical political activities, and avoiding practices that can harm the state and society, such as corruption, collusion, etc nepotism.

An ASN is the main asset in the administration of government. ASN as human resource driving government organizations in carrying out government duties and functions. Every ASN must have integrity, a high sense of nationalism, be professional, and have a global perspective to show good performance, especially in the administration of government, so that the excellent quality of an ASN will be shown by good performance. Especially now that we have entered the era of industry 4.0, every ASN is required to understand and be able to utilize technology to support improving government performance. In the context of ASN management in all agencies, the Indonesian government has issued Law no. 5 of 2014, intending to regulate the governance or management of ASN. This regulation is the government's main foothold for the management or management of ASN so that it can produce ASNs who have professional and excellent performance, have strong fundamental values, can uphold professional ethics, are not involved in practical political activities, are free, and avoid acts of corruption, collusion, and nepotism. In order to carry out good ASN management, every government work unit needs a leader who can encourage each ASN under him to be able to perform well and carry out community service tasks to the fullest. 
The Government of Indonesia has issued Presidential Regulation of the Republic of Indonesia No. 81 of 2010 has drafted the Grand Design of Bureaucratic Reform 2010-2025, which was then implemented through the issuance of the Regulation of the Minister of PAN and RB of the Republic of Indonesia No. 25 of 2020 concerning the Bureaucratic Reform Road Map, one of which is through the simplification of institutions or bureaucratic structures. Strengthening and structuring government agencies institutions are held to find the right profile of a government institution to get a formula that has the proper function, process, and size. At this time, every government agency faces challenges or problems that are not easy, intending to compete with bureaucratic patterns in developed countries.

The Immigration Division of the Regional Office of the Ministry of Law and Human Rights Kepulauan Riau as one of the extensions of the Directorate General of Immigration is one of the working areas that have a large number of Immigration Analysts Certain Functional Officers, to support the implementation of policies in the field of immigration following the laws and regulations that have been determined in the region Kepulauan Riau. Certain Functional Officials of Immigration Analysts are the spearheads in implementing bureaucratic reforms launched by the government, especially in immigration. For this reason, it takes individuals who have a New Public Management work concept that emphasizes bureaucrats who are capable, creative, innovative, flexible, and sensitive. Service as ASN. To be able to implement New Public Management properly, one of which requires a type of leader with a transformational leadership style who is expected to have the ability to encourage subordinates, especially certain functional officials of Immigration Analysts to improve the performance of the Immigration Division of the Regional Office of the Ministry of Law and Human Rights Kepulauan Riau.

\section{Literature Review}

The concept of transformational leadership was first developed by Burns (1978) and Bass (1985), which was based on the leadership style of political figures in the United States and then applied in an organizational context. According to Basstransformational leadership conceptually and theoretically, it is understood as a leadership style that can encourage the involvement of subordinates, inspire subordinates, and have a commitment with their subordinates to achieve organizational goals. Challenge subordinates to become problem-solving skills, encouraging subordinates to innovate in completing tasks. Furthermore, improve the ability of subordinates by providing training, training, encouragement, and support in carrying out the work (Bass, 1985). According to (Bass \& Riggio, 2006; Bass \& Steidlmeier, 1999), in theory, transformational leadership has four essential components. The first component is idealized influence. The second component is inspirational motivation (providing motivation). A leader with a transformational style has behavior that motivates and inspires subordinates around them. The third component of intellectual stimulation (encouraging intellectually). A leader with a transformational style encourages subordinates to innovate and have creativity through providing input, approaches to a problem, and how to solve problems in new ways. The fourth component is individualized consideration. A leader with a transformational style will pay special attention to what is needed by each subordinate in achieving and improving work by acting as a coach or mentor.

In general, Indonesia's public sector bureaucratic system still has a central, formal, and routine nature. Therefore, to keep up with public administration that is developing so fast, especially now that the concept of public administration puts forward more new public management (NPM). This concept, which is based on creative, innovative, flexible work procedures, the responsiveness of a public organization, transformational leadership style, is very appropriate for every leader in the government work unit (Breevaart et al., 2016). Thamrin, 2012 found that transformational leadership has a significant and significant effect on employee performance. Research (Pourbarkhordari et al., 2016) found that transformational leadership significantly influences employee performance. Research (Manzoor et al.) that transformational leadership significantly affects employee performance. Research (Buil et al., 2018) explains that transformational leadership has a significant but insignificant effect on employee performance. (Breevaart et al., 2016) stated that the four components of transformational leadership (idealized influence, inspirational motivation, individual stimulation, and intellectual consideration) have a significant and significant effect on employee performance.

Kahn (1990) is a pioneer researcher in developing the concept of engagement by stating that an engaged employee is a person who has an emotional relationship with work and other individuals physically, cognitively, and emotionally. (Bakker \& Bal, 2010) defines employee engagement as a motivational concept. Employees are committed to achieving organizational goals and have a sense of enthusiasm to give all their energy for their work. (Bakker 2006) suggests that employee engagement is an employee's psychological attachment to work, which is very much needed in modern organizations. Furthermore (Doornen et al., 2009) conceptualize that employee engagement is the opposite of burnout. Furthermore, employee engagement and burnout are opposite in implementing a job related to welfare, where burnout is on the negative pole, and employee engagement is on the positive pole.

Research (Pourbarkhordari et al., 2016) found that employee engagement positively and significantly affects employee performance. Research (Bakker \& Bal, 2010) found that employee engagement has a significant and significant effect on employee performance. Research (Eldor \& Harpaz, 2016) found that 
employee engagement positively and significantly affects employee performance. The engagement has a positive and significant effect on employee performance. Research (Karatepe, 2013) found that employee engagement positively and significantly affects employee performance. Research conducted by (Kingdom \& Periodicals, 2013) found that employee engagement positively and significantly affects employee performance. Research (Authors, 2014) found that employee engagement positively and significantly affects employee performance. Research (Chen, 2015) found that employee engagement positively and significantly influences employee performance. Research (Shams et al., 2018) found that employee engagement positively and significantly influences employee performance. Research (Bedarkar \& Pandita, 2014) found where employee engagement has a positive and significant effect on employee performance.

Research that examines the effect of transformational leadership on employee performance using employee engagement as a mediation variable has been widely studied. Research conducted by (Salanova et al., 2011) found that employee engagement significantly affects the relationship between transformational leadership and employee performance, so employee engagement is complete mediation. ( Breevaart et al., 2016) found that employee engagement significantly influences the relationship between transformational leadership and employee performance, so employee engagement is complete mediation. The results of a different study conducted by (Pourbarkhordari et al., 2016) found that employee engagement had an effect but not significant on the relationship between transformational leadership and employee performance so that employee engagement was partial mediation. (Buil et al., 2018) found that employee engagement had an effect but not significant to the relationship between transformational leadership and employee performance, so employee engagement is partial mediation.

\section{Research Model and Hypothesis}

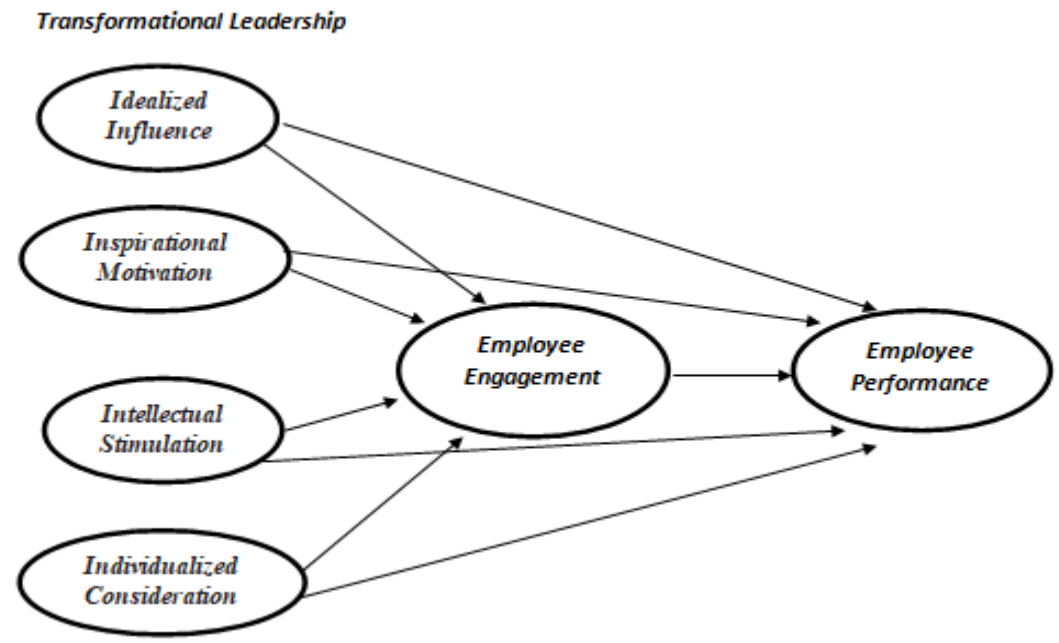

Figure 1. Research Model

H1: Idealized influence positive and significant effect on employee performance.

$\mathrm{H} 2$ : Idealized influence positive and significant effect on employee engagement.

H3: Inspirational motivation positive and significant effect on employee performance.

H4: Inspirational motivation positive and significant effect on employee engagement.

H5: Intellectual stimulation positive and significant effect on employee performance.

H6: Intellectual stimulation positive and significant effect on employee engagement.

H7: Individualized consideration positive and significant effect on employee performance.

H8: Individualized consideration positive and significant effect on employee engagement.

H9: Employee engagement positive and significant effect on employee performance.

H10: Idealized influence positively and significantly affects employee performance with mediation employee engagement.

H11: Inspirational motivation positive and significant effect on employee performance with mediation employee engagement.

H12: Intellectual stimulation positive and significant effect on employee performance with mediation employee engagement.

H13: Individualized consideration positive and significant effect on employee performance with mediation employee engagement.

\section{Research Methods}

The population in this study is employees who work under the Regional Office of the Ministry of Law and Human Rights, Riau Islands Province. The target population in this study is employees who have certain functional positions of Immigration Analyst under the Regional Office of the Ministry of Law and Human 
Rights, Province Kepulauan Riau. The sample unit used is side random. This research was conducted at the Regional Office of the Ministry of Law and Human Rights of the Province Kepulauan Riau. The total population of this study is 216 employees.

The primary data used in this study will be obtained by researchers through questionnaires directly to respondents. The distribution of the questionnaires was carried out through an online survey (Google Form). The researcher collects the respondent's WhatsApp contact number and then sends a google form link via the WhatsApp application to each respondent. Data analysis techniques are used to answer the problem formulation or test the hypotheses that have been formulated. Management of data in this study will use software smartPLS 3.0. According to experts, the Structural Equation Modeling (SEM) research method is grouped into two approaches, namely the Covariance Based SEM (CBSEM) and Variance Based SEM or Partial Least Square (PLS) approach.

\section{Result and Discussion}

Testing research data with Convergent Validity to see if the question items in the research are reliable. The reliability value (validity indicator) can be seen from the loading factor value of each questionnaire item indicator. The correlation between questionnaire items is shown based on the loading factor value. Each questionnaire item is valid if it has a loading factor value $>0.7$; on the other hand, if the question item loading factor value is $<0.7$, the question item should be removed from the data test because it is not reliable. Based on the results of the Convergent Validity test data using the PLS 3.0 smart application, it was found that the loading factor value of all question items > 0.7 as presented in table 1 below:

Table 1. Question Item Loading Factor

\begin{tabular}{|c|c|c|}
\hline Variable & Indicator & Outer Loading \\
\hline \multirow[t]{8}{*}{ Idealized Influence } & II1 & 0.781 \\
\hline & II2 & 0.808 \\
\hline & II3 & 0.710 \\
\hline & II4 & 0.774 \\
\hline & II5 & 0.766 \\
\hline & II6 & 0.758 \\
\hline & II7 & 0.853 \\
\hline & II8 & 0.750 \\
\hline \multirow[t]{4}{*}{ Inspirational Motivation } & IM1 & 0.846 \\
\hline & IM2 & 0.887 \\
\hline & IM3 & 0.875 \\
\hline & IM4 & 0.901 \\
\hline \multirow[t]{4}{*}{ Intellectual Stimulation } & IS1 & 0.831 \\
\hline & IS2 & 0.853 \\
\hline & IS3 & 0.873 \\
\hline & IS4 & 0.892 \\
\hline \multirow[t]{4}{*}{ Individualized Consideration } & IC1 & 0.848 \\
\hline & IC2 & 0.826 \\
\hline & IC3 & 0.916 \\
\hline & IC4 & 0.919 \\
\hline \multirow[t]{9}{*}{ Employee Engagement } & EE1 & 0.817 \\
\hline & EE2 & 0.862 \\
\hline & EE3 & 0.762 \\
\hline & EE4 & 0.780 \\
\hline & EE5 & 0.829 \\
\hline & EE6 & 0.775 \\
\hline & EE7 & 0.778 \\
\hline & EE8 & 0.814 \\
\hline & EE9 & 0.832 \\
\hline \multirow[t]{3}{*}{ Employee Performance } & EP1 & 0.799 \\
\hline & EP2 & 0.741 \\
\hline & EP3 & 0.767 \\
\hline
\end{tabular}




\begin{tabular}{ccc}
\hline & EP4 & 0.706 \\
\cline { 2 - 3 } & EP5 & 0.756 \\
\cline { 2 - 3 } & EP6 & 0.770 \\
\cline { 2 - 3 } & EP7 & 0.806 \\
\cline { 2 - 3 } & EP8 & 0.836 \\
\hline & EP9 & 0.747 \\
\hline
\end{tabular}

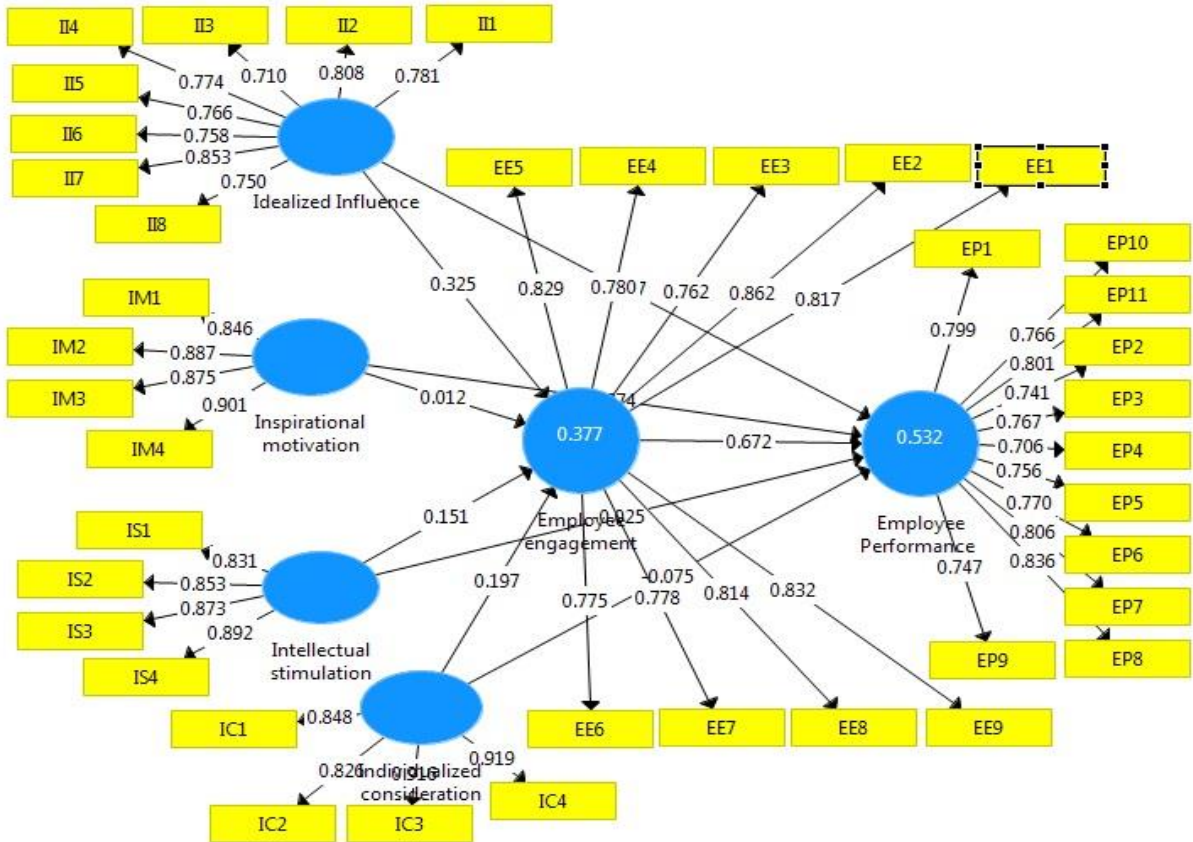

Figure 1. Smart PLS Testing Research Model

The following analysis measures the value of Average Variance Extracted (AVE). Discriminant validity of a research model is said to be good if the Average Variance Extracted (AVE) of all variable items has a value greater than 0.5. The results of measuring the Average Variance Extracted (AVE) value using the smartPLS 3.0 application in this study are presented in table 2 below:

Table 2 Average Variance Extracted (AVE)

\begin{tabular}{ll}
\hline \multicolumn{1}{c}{ Variable } & AVE \\
\hline Idealized Influence (II) & 0.602 \\
\hline Inspirational Motivation (IM) & 0.770 \\
\hline Intellectual Stimulation (IS) & 0.744 \\
\hline Individualized Consideration (IC) & 0.772 \\
\hline Employee Engagement (WE) & 0.650 \\
\hline Employee Performance (EP) & 0.598 \\
\hline
\end{tabular}

Variant analysis (R2) is used to measure how much influence the independent variable has on the dependent variable. The higher the r-square value, the result of the Analysis Variant (R2) test indicates that the research model is getting better. This means that the greater the value of $r$-square, the greater the influence of the independent variable on the dividend variable; conversely if the value of the r-square is low, the influence of the independent variable on the dividend variable will be smaller. The results of the Analysis of Variant (R2) measurement using the smartPLS 3.0 application in this study are presented in table 3 below:

$\begin{array}{r}\text { Table 3. R-square } \\ \hline \text { Value r-square } \\ \hline 0.532 \\ \hline 0.377 \\ \hline\end{array}$

Analysis of Variant (R2) testing in this research using the smartPLS 3.0 application, the measurement results are depicted in table 4.3, showing the influence of independent variables on low dividend variables. The results of the data processing test show that the magnitude of the influence of the independent variable 
on the employee performance variable is 0.532 . This means that the four independent variables, idealized influence, inspirational motivation, intellectual stimulation, and individualized consideration, are able to explain the employee performance variable by $53.2 \%$, and the remaining $46.8 \%$ is influenced by other variables not raised in this study. Furthermore, the influence of the independent variable on the employee engagement variable is 0.377. This means that the four independent variables, idealized influence, inspirational motivation, intellectual stimulation, and individualized consideration can explain the employee engagement variable by $37.7 \%$, and the remaining $62.3 \%$ is influenced by other variables not raised in this study.

After completing the Analysis of Variant (R2) testing, the next test is hypothesis testing. The results of hypothesis testing are measured by analyzing the $r$-square output value, parameter coefficients, and $t-$ statistics obtained from the bootstrapping results. Variables obtained from the test results. This study's standard measurement of value is the t-statistic value $>1.96$, with a significant level of $p$-value $<0.05(5 \%)$, and the beta coefficient has a positive value.

Table 4. Path Coefficients

\begin{tabular}{lrrrrr}
\hline \multicolumn{1}{c}{ Hypothesis } & $\begin{array}{c}\text { Original } \\
\text { Sample (O) }\end{array}$ & $\begin{array}{c}\text { Sample } \\
\text { Mean (M) }\end{array}$ & $\begin{array}{c}\text { Standard Deviation } \\
\text { (STDEV) }\end{array}$ & T-Statistics & P-values \\
\hline $\mathrm{II} \rightarrow$ EP & 0.117 & 0.103 & 0.113 & 1.039 & 0.299 \\
\hline $\mathrm{II} \rightarrow$ EE & 0.325 & 0.331 & 0.119 & 2.722 & 0.007 \\
\hline IM $\rightarrow$ EP & 0.074 & 0.063 & 0.103 & 0.723 & 0.470 \\
\hline IM $\rightarrow$ EE & 0.012 & 0.016 & 0.115 & 0.108 & 0.914 \\
\hline IS $\rightarrow$ EP & -0.025 & -0.013 & 0.116 & 0.217 & 0.828 \\
\hline IS $\rightarrow$ EE & 0.151 & 0.154 & 0.124 & 1.220 & 0.223 \\
\hline IC $\rightarrow$ EP & -0.075 & -0.057 & 0.099 & 0.754 & 0.451 \\
\hline IC $\rightarrow$ EE & 0.197 & 0.195 & 0.107 & 1.841 & 0.066 \\
\hline EE $\rightarrow$ EP & 0.672 & 0.666 & 0.064 & 10.494 & 0.000 \\
\hline
\end{tabular}

Table 5. Results specific indirect effects

\begin{tabular}{lrrrrr}
\hline Hypothesis & $\begin{array}{c}\text { Original } \\
\text { sample }(\mathrm{O})\end{array}$ & $\begin{array}{c}\text { Sample } \\
\text { Mean }(\mathrm{M})\end{array}$ & $\begin{array}{c}\text { Standard Deviation } \\
(\text { STDev })\end{array}$ & T-Statistics & P-Values \\
\hline $\mathrm{II} \rightarrow \mathrm{EE} \rightarrow \mathrm{EP}$ & 0.218 & 0.221 & 0.083 & 2.628 & 0.009 \\
\hline $\mathrm{IM} \rightarrow \mathrm{EE} \rightarrow \mathrm{EP}$ & 0.008 & 0.011 & 0.077 & 0.108 & 0.914 \\
\hline $\mathrm{IS} \rightarrow \mathrm{EE} \rightarrow \mathrm{EP}$ & 0.101 & 0.102 & 0.083 & 1.224 & 0.222 \\
\hline $\mathrm{IC} \rightarrow \mathrm{EE} \rightarrow \mathrm{EP}$ & 0.132 & 0.130 & 0.072 & 1.846 & 0.065 \\
\hline
\end{tabular}

Table 6. Summary of hypothesis testing results

\begin{tabular}{lllc}
\hline & Hypothesis & \multicolumn{1}{c}{ Results } & Conclusion \\
\hline $\mathrm{H}_{1}$ & II $\rightarrow$ EP & Insignificant influence & Rejected \\
\hline $\mathrm{H}_{2}$ & II $\rightarrow$ EE & Significant influence & Accepted \\
\hline $\mathrm{H}_{3}$ & IM $\rightarrow$ EP & Insignificant influence & Rejected \\
\hline $\mathrm{H}_{4}$ & IM $\rightarrow$ EE & Insignificant influence & Rejected \\
\hline $\mathrm{H}_{5}$ & IS $\rightarrow$ EP & Insignificant influence & Rejected \\
\hline $\mathrm{H}_{6}$ & IS $\rightarrow$ EE & Insignificant influence & Rejected \\
\hline $\mathrm{H}_{7}$ & IC $\rightarrow$ EP & Insignificant influence & Rejected \\
\hline $\mathrm{H}_{8}$ & IC $\rightarrow$ EE & Insignificant influence & Rejected \\
\hline $\mathrm{H}_{9}$ & EE $\rightarrow$ EP & Significant influence & Accepted \\
\hline $\mathrm{H}_{10}$ & II $\rightarrow$ EE $\rightarrow$ EP & Significant influence & Accepted \\
\hline $\mathrm{H}_{11}$ & IM $\rightarrow$ EE $\rightarrow$ EP & Insignificant influence & Rejected \\
\hline $\mathrm{H}_{12}$ & IS $\rightarrow$ EE $\rightarrow$ EP & Insignificant influence & Rejected \\
\hline $\mathrm{H}_{13}$ & IC $\rightarrow$ EE $\rightarrow$ EP & Insignificant influence & Rejected \\
\hline
\end{tabular}

\section{Conclusion}

The implementation of this study was conducted to find answers to the questions in the formulation of the problem posed in the study, namely whether transformational leadership factors have a significant influence on employee performance and whether employee engagement factors affect the relationship between transformational leadership and employee performance. Based on the results of research that has been carried out on certain Functional Officers of Immigration Analysts in the Immigration Division of the Regional Office of the Ministry of Law and Human Rights, Riau Islands, it was found that:

1. This study found that the elements of transformational leadership idealized influence, inspirational motivation but not significant effect on employee performance, but intellectual stimulation and individualized consideration had no effect. 
2. This study found that employee engagement strengthens the relationship between transformational leadership ((idealized influence, inspirational motivation, intellectual stimulation, and individualized consideration) with employee performance.

\section{Limitations and Recommendations}

In the implementation of this research, there are still limitations, thus affecting the study results. Limitations in the research that has been carried out are caused by several things, namely: The level of occupancy of the questionnaire is $75 \%$ of the total respondents, for further research, it is better than the occupancy rate of the questionnaire can reach close to $100 \%$ to obtain more accurate research results. The objects in this study are limited to employees of certain functional officials, immigration analysts who work in the Immigration Division of the Riau Islands Ministry of Law and Human Rights Regional Office. It is advisable for further research to expand the object of research, such as covering all employees or expanding the scope of the research area. The influence of independent variables on employee performance is still low, indicating that employee performance is influenced by transformational leadership style factors and influenced by other leadership styles.

For further research, it is necessary to consider: The object of this research is the employee of a particular functional officer of the Immigration Analyst who works in the Immigration Division of the Regional Office of Kemenkumham Riau Islands. This research model uses transformational leadership (idealized influence, inspirational motivation, intellectual stimulation, and individualized consideration) to affect employee performance; for further research, it is necessary to expand the research variables so that results are compared between types of leadership styles that affect employee performance.

Based on the results of this study, it was found that transformational leadership variables (idealized influence, inspirational motivation, intellectual stimulation, and individualized consideration) affect employee performance. Some things that need to be considered in the transformational leadership style include making the leader a role model for subordinates, motivating and inspiring subordinates by giving challenges to the work that must be done by subordinates and encouraging expectations of goals to be achieved, increasing subordinate awareness to look at problems from a new perspective, and provide support and encouragement to subordinates and establish two-way communication with subordinates.

\section{References}

Ancok, Djamaludin. (2012). Psikologi Kepemimpinan \& Inovasi.Yogyakarta : Penerbit Erlangga.

Authors, F. (2014). Determinants of employee engagement and their impact on employee performance. https://doi.org/10.1108/IJPPM-01-2013-0008

Azka, G., Tahir, M. Q., M, A. K., \& Syed, T. H. (2011). Transformational leadership, employee engagement, and performance: Mediating effect of psychological ownership. African Journal of Business Management, 5(17), 7391-7403. https://doi.org/10.5897/ajbm11.126

Bakker, A. B. (2006). The Measurement of Short Questionnaire A Cross-National Study. 701-716.

Bakker, A. B., \& Bakker, A. B. (2011). Current Directions in Psychological Science. https://doi.org/10.1177/0963721411414534

Bakker, A. B., \& Bal, P. M. (2010). Copyright (C) The British Psychological Society Weekly work engagement and performance: A study among starting teachers Copyright (C) The British Psychological Society. 189-206. https://doi.org/10.1348/096317909X402596

Bass, B. M. (1985). Leadership: Good, better, best. Organizational Dynamics, 13(3), $26-40$. https://doi.org/10.1016/0090-2616(85)90028-2

Bass, B. M., \& Riggio, R. E. (2006). Transformational Leadership.

Bass, B. M., \& Steidlmeier, P. (1999). Ethics, character, and authentic transformational leadership behavior. Leadership Quarterly, 10(2), 181-217. https://doi.org/10.1016/S1048-9843(99)00016-8

Bedarkar, M., \& Pandita, D. (2014). A study on the drivers of employee engagement impacting employee performance. Procedia - Social and Behavioral Sciences, 133, 106-115. https://doi.org/10.1016/j.sbspro.2014.04.174

Besieux, T., Baillien, E., Verbeke, A. L., \& Euwema, M. C. (2018). What goes around comes around: The mediation of corporate social responsibility in the relationship between transformational leadership and employee engagement. Economic and Industrial Democracy, 39(2), 249-271. https://doi.org/10.1177/0143831X15614914

Breevaart, K., Bakker, A. B., Demerouti, E., \& Derks, D. (2016). Who takes the lead ? A multi-source diary study on leadership, work engagement, and job performance. 325(October 2014), 309-325. https://doi.org/10.1002/job

Breevaart, K., Bakker, A., Hetland, J., Demerouti, E., Olsen, O. K., \& Espevik, R. (2014). Daily transactional and transformational leadership and daily employee engagement. Journal of Occupational and Organizational Psychology, 87(1), 138-157. https://doi.org/10.1111/joop.12041

Buil, I., Martínez, E., \& Matute, J. (2018). International Journal of Hospitality Management Transformational leadership and employee performance: The role of identity fi cation, engagement and proactive personality. October 2017. https://doi.org/10.1016/j.ijhm.2018.06.014 
Chen, S. (2015). A multilevel mediating perspective is a relationship between leader psychological capital and follower psychological capital, job engagement, and job performance. 5192(November 2016). https://doi.org/10.1080/09585192.2015.1020443

Doornen, L. J. P. Van, Houtveen, J. H., Langelaan, S., Arnold, B., Rhenen, W. Van, \& Schaufeli, W. B. (2009). Burnout versus work engagement in their effects on 24-hour ambulatory monitored cardiac autonomic function. 331(April), 323-331. https://doi.org/10.1002/smi.1279

Eldor, L., \& Harpaz, I. (2016). A process model of employee engagement: The learning climate and its relationship with extra-role performance behaviors. 235(October 2014), 213-235. https://doi.org/10.1002/job

Eliyana, A., \& Ma, S. (2019). Job satisfaction and organizational commitment affect transformational leadership towards employee performance. European Research on Management and Business Economics, 25(3), 144-150. https://doi.org/10.1016/j.iedeen.2019.05.001

Indriantoro,Nur dan Bambang Supomo. (2011). Metodologi Penelitian Bisnis Untuk Akuntansi Dan Manajemen, Edisi Pertama. BPFE, Yogyakarta

Jyoti, J., \& Bhau, S. (2015). Impact of Transformational Leadership on Job Performance: Mediating Role of Leader-Member Exchange and Relational Identification. SAGE Open, 5(4). https://doi.org/10.1177/2158244015612518

Karatepe, O. M. (2013). International Journal of Hospitality Management High-performance works practices and hotel employee performance: The mediation of work engagement. International Journal of Hospitality Management, 32, 132-140. https://doi.org/10.1016/j.ijhm.2012.05.003

Kingdom, U., \& Periodicals, W. (2013). K E R S T I N A L F E S, C AT H E R IN T R U S S, E M M A C .52(6), 839-859. https://doi.org/10.1002/hrm

Lee, P. K. C., Cheng, T. C. E., Yeung, A. C. L., \& Lai, K. (2011). An empirical study of transformational leadership, team performance, and service quality in retail banks. Omega, 39(6), 690-701. https://doi.org/10.1016/j.omega.2011.02.001

Manzoor, F., Wei, L., Nurunnabi, M., \& Subhan, Q. A. (n.d.). The Impact of Transformational Leadership on Job Performance and CSR as Mediator in SMEs. 1-14. https://doi.org/10.3390/su11020436

Mozammel, S., \& Haan, P. (2016). Transformational leadership and employee engagement in the banking sector in Bangladesh. The Journal of Developing Areas, 50(6), 43-55. https://doi.org/10.1353/jda.2016.0127

Nguyen, D. L. (2020). Mediating the role of psychological empowerment between transformational leadership and employee engagement. Management Science Letters, 10(16), 4039-4044. https://doi.org/10.5267/j.msl.2020.7.005

Pourbarkhordari, A., Hua, E., Zhou, I., \& Pourkarimi, J. (2016). How Individual-focused Transformational Leadership Enhances Its Influence on Job Performance through Employee Work Engagement. 11(2), 249-261. https://doi.org/10.5539/ijbm.v11n2p249

Salanova, M., Lorente, L., Chambel, M. J., \& Mart1, I. M. (2011). Linking transformational leadership to nurses' extra-role performance: the mediating role of self-efficacy and work engagement. https://doi.org/10.1111/j.1365-2648.2011.05652.x

Salau, O., Oludayo, O., Falola, H., Olokundun, M., Ibidunni, S., \& Atolagbe, T. (2018). Integrated datasets on transformational leadership attributes and employee engagement: The moderating role of job satisfaction in the Fast Moving Consumer Goods (FMCG) industry. Data in Brief, 19, 2329-2335. https://doi.org/10.1016/j.dib.2018.06.032

Shams, A., Mahmudul, M., Sciences, M., Awang, Z. Bin, Sciences, M., Siddiqui, B. A., Sabiu, M. S., Ali, U., \& Polytechnic, S. (2018). Role of Employee Engagement on Compensation System and Employee Performance Relationship among Telecommunication Service Providers in Bangladesh. 8(3), 19-37. https://doi.org/10.5296/ijhrs.v8i3.13081

Singh, A. (2019). Transformational Leadership in Enhancing Employee Engagement: Evolving Issues and Direction for Future Research through Literature Review. SSRN Electronic Journal, 878-893. https://doi.org/10.2139/ssrn.3316331

Sugiyono. (2015). Metode Penelitian Kuantitatif, Kualitatif dan R\& D. Alfabeta, Bandung

Thamrin, H. M. (2012). The Influence of Transformational Leadership and Organizational Commitment on Job Satisfaction and Employee Performance. 3(5). https://doi.org/10.7763/IJIMT.2012.V3.299

Viswesvaran, C., Schmidt, F. L., \& Ones, D. S. (2005). Is there a general factor in job performance ratings? A meta-analytic framework for disentangling substantive and error influences. Journal of Applied Psychology, 90(1), 108-131. https://doi.org/10.1037/0021-9010.90.1.108

Yammarino, F. J., Spangler, W. D., \& Bass, B. M. (1993). Transformational leadership and performance: A longitudinal investigation. The Leadership Quarterly, 4(1), 81-102. https://doi.org/10.1016/10489843(93)90005-E 